\title{
Ideology and the Expression of Brands
}

Jens Martin Svendsen, Stockholm Business School, Stockholm University

As the branding process is intertwined with already existing culturally conditioned conceptions, fundamental cultural processes in a society might affect the attraction of a specific brand. This means that trends of ethical or political fashions influence the popularity of brands and how they are recognized. In his seminal book Brand Society, Martin Kornberger argues that "brands have brought about a new way of living a life: the ubiquitous, pervasive yet little analyzed notion of lifestyle encapsulates brands' power to quite literally stylize life". He points to three influential elements-he calls them a troika-provides a basis for this analysis. These are Politics, Ethics and Aesthetics. (Kornberger, 2010) I will here propose a fourth, namely stories, tales, modes of understanding you might even want to call it. And I hope to show that such stories (understandings) take on the form of ideas and thus can have profound political implications, if not to say that they have ideological origins and in this way far-reaching consequences, the effects on brands just being one of them. This fourth element I prefer to call simply Stories, even though tales would probably be just as appropriate, or even Thought-trends. Ideology could be another possible term, but this is really an outcome rather than a good term in and of itself for what I intend to show. Yet another possibility would be to use the term Myth, then of course with reference to Barthes myth-concept. (Barthes, 1997) His concept has to do with selfdescriptions, mainly focusing on national sentiments and self-understandings of what it might mean to be for instance French or British, Barthes exemplifies by referring to concrete manifestations such as the Eiffel Tower or Five o'clock tea, answers to questions like 'Who are we?' or 'How do people like us live?'. These are national 
myths based on some sort of ethnical factor, living-space if you will. This is however not what I'm focusing on, rather under-currents to thinking of another sort. So I'll just stick with Stories for the time being

To show this, I will take help of a specific case and in so doing focus on its position in the late 60-ties and early 70-ties. The case accordingly focuses on how the brand Fjällräven has been acknowledged as having varying political, ethical and fashionable positioning over decades. The case is compared to another related brand within the outdoor equipment-slash-fashion industry, Haglöfs. Possibly a lesser known brand, and this has its explanations as will be seen.

The term stories might imply storytelling, a term lately frequently used to denote a marketing tool within something in practical marketing coined content marketing. By this one might mean marketing that is not primarily targeted at conveying a simple message pertaining to a customer need or want, rather at building trustworthiness in an attempt to relate to customers sense of belonging or search for ideas and suggestions - the helpful company with a legitimate history and position in society. Storytelling has been the subject of many books, both textbooks and consultancy literature, Brown, (2004), Mossberg \& Nissen Johansen (2006), Thier (2006), to name but a few. Content marketing in not that a novel idea as Pulizzi (2012) contends, it has been around for for hundreds of years. His exampel is John Deere and the compay's strive to educate its customers in how to use equipment. Another example would be Jell-O and their recipies in the early 2oth century. But if this iscontent marketing, it is not stories in the sense i would like to use the term. 
Another aspect of storytelling might be the so called corporate narrative, this phenomenon has been analyzed by many, Barbara Czarniawska $(1997,2005,2009)$ to name but one. She even makes an interesting connection between corporate storytelling and novels, as well as referring storytelling to leadership. In this sence stories and storytelling is not just marketing, it is also part of an organizations inner workings, as leadership and the (possibly co-) creation of a shared identity; it is stories of the self and stories that would contextualize and explain the position of the self, also of course to explain and rationalize the actions taken within the actual context that is described by these stories.

The idea of realization of actions motivated by and pertaining to stories and storytelling in organization and marketing has also been analyzed by Rehnberg (2014) from a linguistic viewpoint, using Fjällräven as an exampel for the analysis. She of course has a much greater scope for her analysis than just actions, but it is one of her vital points. Stories in her sense can be of two kinds, Strategic stories and Common stories, the difference being that Strategic stories are stories that are created by a commercial actor. She talks of stories as chains of text, texts that are stories can be consecutively constructed, an obvious example being blogg texts. These texts develop a story, further Rehnberg points out that they in themselves are inscribed in stories: stories contextualize stories so to speak. These contextualizing stories she calls meta-stories, stories that remain weak in their explicidness, yet strong in their impact. Invisible in details yet most visible in society, both as selfunderstanding of what's importante self-descriptions of the society, even models for explanations. One might come to think about Lyotard and his pivotal work La Condition Postmodern. Lyotards critizises the idea of mega-stories and talks about small, maybe even local, stories. (Lyotard, 1984) A Lyotardian mega-story is one that 
pertains to the whole society, in a sense claims to explain everything in society, a story that tells a bout developlemnt and societal focus and strive; it explains our moment in history and what we are as a society. Lyotard maintains that these stories more or less has outlived themselves. This is what he calls the postmodern condition. Knowledge then has to be construed in other terms than in something under the umbrellla of such a mega-storie, somewhat holistic, i.e. understod in terms of a whole system rather than as disconected units or propositions. His critique can be said to be directed towards ideas that has come to be expressed by people such as the 19th century philosophers and pedagogue Herbert Spencer (1820-1903) and, the better known, John Dewey (1859-1952), and possibly also, at least in an idirect way, the italian philosopher Gianbatista Vico (1668-1744). But in the course of progression of this text, I hope it will be clear that the ideas of these thre very influencial, or semiinfluencial, philosophers, are not totally consistant with each other even though they share some similarities on some level. And of course, that at the point where they share simlarities, they also help to explain the case of Fjällräven.

The American pragmatist John Dewey is one of the heavily influential philosophers during the twentieth century. He can be said to represent a very dominant strain of thought that has its roots in 18th century enlightenment. One early forerunner within the field of pedagogy is the now since long forgotten Herbert Spencer. The strain of thought these philosophers represent can be coined progressivist. The idea within this thought model is that improvement is possible through knowledge, a kind of optimism when it comes to society and human effort to improve its living conditions, and being in the world. But knowledge should and must be rooted in empirical observations. In this way, the study of scripture would not lead to knowledge, at least not of the world in which we live. A boy or a girl (depending if you follow Dewey or 
Spencer) reaches knowledge of the empirical world when confronted with it. The world poses the problems, and the boy or girl looks for solutions to these problems. The problems occur when ambitions to do things are limited in some way, the problem is to overcome these limitations, in this way the solutions have a twopronged grounding: in part in the empirical, in part in the personal. It is driven by personally experienced limitations, and by empirical observations. The same is true of science, Dewey maintains, and in this way all knowledge-seeking. The ideal is the tailor, cabinetmaker and the shoemaker: the craftsman. Knowledge is within the world and about the world. The outcome of knowledge is better living in the world and a better life for the living, thus knowledge is part of the improvement of life for the human beings, society if you will.

This progressivist stance is linked to society and everything in it and thus to brands that accordingly resonates the progressivist beliefs and hopes so that the brand of Fjällräven can be said to be an example of progression in this progressivist tradition. I'll come back to this later.

I have earlier mentioned Giambattista Vico (1664-1744), an Italian philosopher and educator. Contrary to Dewey and Spencer, he describes the development of society in terms of stories resonating in society. Now, one might say that this is just what the progressivist stance is, a story, a tale if you will, of progression and improvement. This stance has very much been the guide of political judgement (an apparent example is Swedish Government Official Reports, this manner of preparing decisions is not uncommon elsewhere either, as far as I know) and pedagogy, where students are urged to find out for themselves, ideas of individualized learning, problem based learning and more. The idea at the core of these methodologies are in all cases that 
student's lust for learning and problem solving is vital for learning. Problem solving and invention is hailed, whilst repetitious repeating of authoritative commandments is unsolicited; progression is also questioning of authorities, sometimes anyway. So if the progressivist stance is a story told, or rather untold but communicated throughout society, it still drives action and strategic choices, and it still is what it is not supposed to be. It is in effect a Lyotardian mega-story, and also a Rehnbergian. Gianbatista Vico argues that a society develops its understanding of itself and its story about itself in three phases, the divine, the heroic and the human. The three phases are characterized by three different approaches to knowledge and truth. The first rather primitive phase, Divine, is characterized by an equation of empirical phenomenon with divine phenomenon. Comprehension is driven by Poetry, Phantasy and Metaphysics, and so builds the basis for construing the world. The metaphor is characterizing this stage, in that the world is described in divine terms that themselves represent rather than present, it is what it is not. The second phase according to Vico is the Heroic. It is described as idealization, institutions are feudal, the central figure of speech is the metonym that one stands for all, the king for the county. Society will be embodied by class difference. The third stage Vico calls the Human phase. Irony and rationalism are characterizing factors, democracy and general laws, too. The phases can appear a trifle optimistic if they are seen as consecutive, which is what I think Vico suggests. The important idea that I want to hold on to here is not the phases progressiveness taken as a whole, rather what they contain by themselves.

Vico's thesis is that truth exists as a consequence of forms of understanding, in the text, in the story resonating within society. This idea I want to use to explain why the progressivist stance can be said to resonate by and with a brand as a token re- 
presentative re-verbarating, i.e. re-stating, the story resonating in a society: a story or rational knowledge-seeking in order to enhance welfare and ease endeavors, solve problems we encounter and make life a smoother and more efficient ride.

With reference to Umberto Eco, Martin Kornberger points out that an author seldom, if ever, has any control over the interpretations of their work. This idea has also been put forward by Paul Ricoeur. This means that the talk, the communicated ideas, the re-verberation if you will, has a greater impact on the meaning of a work than the work itself, the work itself being one of the factors influencing the meaning creating process but not the only. The meaning creating process thus becomes an ever ongoing socially contingent process rather than a stable, once and for all, established fact. Transferred to the field of brands, as Kornberger does, the idea is that brands resonate in society, and they resonate ideas that people have, individuals and collectives. Marcel Danesi voices a similar idea when he affirms that advertising that is in some sense or another successful always resonates with something outside of the brand meaning itself. (Danesi, 2008)An intertextual connection to societal factors. If this is true, then brands resonate not just in an individual sense with individual cocreators, but also in a collective sense with ideas rather than individuals, individuals being the carriers, vehicles if you will, of meaning that co-create meaning but the long term intertextual factors needs to be taken into account. If this is so, then Fjällräven would be a case in point and, further, intertextuality does not need to be communicated explicitly, it is still present, like progressivism is present and thus would influence the meaning construct of a brand, and consequently its sense of significance, value, for want of a better word. 
Fjällräven first saw daylight in 1960. It was started by Åke Nordin as a cellar company. Åke Nordin started out by sowing outdoor equipment of his own design, selling it locally. In less than ten years he had built a company that produced all sorts of equipment, although his original product was rucksacks. These rucksacks had for the time a novel design in the sense that this design was first offered in a commercial situation by Fjällräven. Åke Nordin had built his own carry-frames and sewn his own sacks to go with the frame himself. The design with frames that one can lash one's carrying-load onto was of course not new, what was new was Fjällräven's applications and commercialization of the concept. At the time another outdoor-equipment supplier was very well established on the Swedish market, Haglöfs. In 1914 the entrepreneur Wiktor Haglöf started the self-named business. He began his business in a very similar way to Åke Nordin, by selling rucksack of his own make, primarily to local farmers and loggers. The Haglöf business grew as his rucksacks were perceived as modern and would meet high demands on quality in the wear and tear of the logger's and farmer's hard work. The rucksacks of the Haglöf make were even chosen by the Swedish army and used well into the 70-ties. The Haglöf rucksacks were robust and heavy. One voiced from the time-early 70-ties-stated that if you wanted a rucksack to last forever, then you should choose a Haglöfs. But if you wanted something sleek, slender and light-weight, then Fjällräven would be the preferred the choice. The thing that is voiced here is significant in more than one way, I think. First, a quality argument is not always sustainable. Second, what is perceived as 'the best' is not always obvious. Third, success breeds success in a very specific fashion.

What is put forward is the choice between a quality condition and something else, what this something else is, is not exactly clear, more of a feeling than something apparent and markedly substantial in a tangible respect. Except maybe for the 
weight-factor, which can be interpreted in quite another direction, light-weight meaning fragile, even delicate. In fact, the voice hinted in that direction by supplementing the assessment by saying that if one would venture to drop the Haglöfs rucksack from way up high onto a hard surface it would sustain the fall and still be in a usable state. It was thus maintained that that would not be the case with a rucksack from Fjällräven. So one might think that any rational ourdoorer (hiker or backpacker) would pick the rucksack with the most likelihood to sustain harsh conditions as the Swedish army in those days did, but that is not so, not in all cases anyway, since the Fjällräven rucksack with its concept of a frame onto which the actual sacks were fastened. The concept was, at least for some, obviously more important than durability. But another explanation is possible to, as I see it, and that explanation has to do with fashion: it was more fashionable for some people to carry your things in a Fjällräven rucksack than in a Haglöfs. If this is true then this fashionablity needs explaining, and it is precisely here that the tell-tale stories plays vital role. During the 19th and 2oth centuries a strong undercurrent was the progressivist stance: progress, strive for discoveries, inventions, the future is the important age-past is bygones-political inventions to better society, social inventions to better life, inventions in the field of technology, interventions to improve individuals as well as collectives. Fjällräven presented such an invention that intervened in the life of backpackers as well as outdoorers, the hikers of the time. The invention was the fashionable, the progressive-the political if you will-that bettered life. This progressiveness was the social wave that Fjällräven could surf on and it became the wave of success for Fjällräven that the firm still seems to surf on. Haglöfs was left behand. and possibly still is. The invention was not first and foremost a technological invention as an instance in the tale of progress; a social synergy. 
Following Danesi, a valid story is a story that has the ability to attract sentiment, a story that will inscribe and make sense in terms of a synergetic effect. If the undercurrent is progressivism and that story rationalizes Fjällräven and their offering to users of rucksacks in terms of a story of progression, then that would account for the position Fjällräven got, and, at least to a degree, still might retain. This last point, though, is left for another presentation. 
Barthes, R., 1997. The Eiffel Tower and Other Mythologies. Berkeley and Los Angeles: University of California Press.

Brown, J. S., 2004. Storytelling in organizations : why storytelling is transforming 21st century organizations and management. Burlington, Mass.: ButterworthHeinemann.

Czarniawska, B., 1997. Narrating the organization. Dramas of institutionalized identity. Chicago: The Universitu of Chicago Press.

Czarniawska, B., 2005. Omaka par. Organisationsteori och Skönlitteratur. Göteborg: Fabel.

Czarniawska, B., 2009. Storytelling. Ledarnaasnya verktyg. i: S. Jönsson \& L. Strannegård, red. Ledarskapsboken. Malmö: Liber, pp. 300-315.

Danesi, M., 2008. Why it sells : decoding the meanings of brand names, logos, ads, and other marketing and advertising ploys. Lanham: Rowman \& Littlefield. Kornberger, M., 2010. Brand Society, how brands transform management and lifestyle. New York: Cambridge University Press.

Lyotard, J.-F., 1984. The postmodern condition : a report on knowledge. Manchester: Manchester University Press.

Mossberg, L. \& Nissen Johansen, . E., 2006. Storytelling : marknadsföring $i$ upplevelseindustrin. Lund: Studentlitteratur.

Pulizzi, J., 2012. The Rise of Storytelling as the New Marketing. Publishing Research Quarterly, 28(2), pp. 116-123.

Rehnberg, H. S., 2014. Organisationer berättar: narrativitet som resurs i strategisk kommunikation. Uppsala: Swedish Science Press.

Thier, K., 2006. Storytelling. u.o.:Springer-Verlag. 